\title{
Alterations in the biochemistry and ultrastructure of the deep abdominal flexor muscle of the Norway lobster Nephrops norvegicus during infection by a parasitic dinoflagellate of the genus Hematodinium
}

\author{
G. D. Stentiford ${ }^{1, *}$, D. M. Neil ${ }^{1}$, G. H. Coombs ${ }^{2}$ \\ ${ }^{1}$ Division of Environmental and Evolutionary Biology, University of Glasgow, Glasgow G12 8QQ, Scotland, UK \\ ${ }^{2}$ Laboratory for Biochemical Parasitology, Division of Infection and Immunity, University of Glasgow, Glasgow G12 8QQ, \\ Scotland, UK
}

\begin{abstract}
Changes in various biochemical and ultrastructural characteristics of the deep abdominal flexor (DAF) muscles were studied in Norway lobster Nephrops norvegicus (L.) from the Clyde estuary, Scotland, UK, at different stages of infection by a parasitic dinoflagellate of the genus Hematodinium. Abdominal DAF muscles from infected lobsters showed slight, significant increases in total water content, along with greatly depleted glycogen reserves and an altered free amino acid profile. However, protein concentration and composition remained unchanged. Ultrastructurally, parasitic infection of DAF muscle fibres caused alterations in sarcolemmal structure, and localized disruption of myofibrillar bundles around the periphery, but not throughout the centre of the fibres. Overall, the reduction in swimming performance previously reported for $N$. norvegicus during Hematodinium infection reflect an alteration in carbohydrate supply to the active muscle and some subtle disruption of muscle structure. The altered carbohydrate titre could reflect the Hematodinium parasites acting as a carbohydrate sink in the haemolymph, a disruption of normal tissue glycogenesis, or some alteration in the host's hormonal regulation. These changes could also adversely affect the taste, texture and marketability of infected meat.
\end{abstract}

KEY WORDS: Abdominal muscle $\cdot$ Free amino acids $\cdot$ Glycogen $\cdot$ Hematodinium $\cdot$ Nephrops norvegicus $\cdot$ Protein $\cdot$ SDS-PAGE $\cdot$ Water content

\section{INTRODUCTION}

Damage to crustacean muscle has been widely reported from various infective agents, including microsporidians (Findley et al. 1981, Langdon 1991, Kabre 1992, Dennis \& Munday 1994, Childers et al. 1996), ciliates (Cawthorn 1997), bacteria (Stewart 1980) and dinoflagellates (Shields 1994). Other studies have described muscle wastage with unknown etiology (Lindqvist \& Mikkola 1978), while host-induced (idiopathic) muscle necrosis can occur with natural or artificial stress (Akiyama et al. 1982, Anderson et al. 1990, G.D.S. \& D.M.N. unpubl. data). Such changes in

*E-mail: g.stentiford@udcf.gla.ac.uk the biochemical composition of muscle tissue can have economic consequences, as in the case of Tanner crabs (Chionoecetes bairdi and C. opilio) infected by a parasitic dinoflagellate (Hematodinium sp.) which causes the so-called 'bitter crab disease'. In this case infected muscle tissue tastes bitter (Meyers et al. 1987) and is sometimes deemed to be unmarketable (Eaton et al. 1991, Taylor \& Khan 1995). Similar observations have also been reported for Hematodinium sp. infections of other commercially important crustaceans, including the sand crab Portunus pelagicus (Hudson 1995) and the blue crab Callinectes sapidus (Messick 1994).

Populations of the Norway lobster Nephrops norvegicus from the west coast of Scotland are seasonally infected with a dinoflagellate of the genus Hematodinium, with prevalence levels of over $70 \%$ in some 
years (Field et al. 1992). Several studies have established the progression, diagnosis and pathology of Hematodinium infection in $N$. norvegicus (Field \& Appleton 1995, 1996), and its effect on host physiology (Taylor et al. 1996) and haemolymph biochemistry (Stentiford et al. 1999).

During late infections the deep abdominal flexor (DAF) muscles of Nephrops norvegicus, which are mainly responsible for the rapid abdominal flexion in 'tail flip' swimming in these lobsters (Newland \& Neil 1990), are partially invaded by the Hematodinium parasite (Field \& Appleton 1995). The abdominal musculature may also be altered in water content during Hematodinium infection in $N$. norvegicus, similar to Hematodinium sp. infections in other commercially important crustaceans (Meyers et al. 1987, Messick 1994, Hudson 1995). Such changes in the structure and composition of DAF muscles could lead to altered contractile behaviour (Field et al. 1995). Deficits in the swimming performance have been measured in Hematodinium-infected individuals (Stentiford et al. 2000). This has important consequences for the success of infected lobsters in escaping from predators (Neil \& Ansell 1995, Arnott et al. 1998) and in evading capture by trawl nets (Newland et al. 1992). Additionally, the texture and taste quality of the tail meat, the marketable product of a large Scottish fishery ( $\$ 48 \mathrm{M}$ in 1998) (FRS 1999), may also be altered.

Despite their potentially damaging effect, changes in the biochemistry and ultrastructure of the DAF muscles in Hematodinium-infected Nephrops norvegicus have never been studied systematically (Field et al. 1992, 1995). Therefore in this study the water content, total protein, glycogen and free amino acids (FAA) of DAF muscle fibres were measured in $N$. norvegicus at different stages of Hematodinium infection and related to changes in the ultrastructure of the muscle fibres.

\section{MATERIALS AND METHODS}

Specimens. Norway lobsters Nephrops norvegicus (L.) were caught by otter-trawl from a location south of Little Cumbrae in the Clyde Sea area, Scotland, UK, and subsequently maintained in a closed aquarium $\left(10^{\circ} \mathrm{C}, 33 \mathrm{ppt}\right.$ salinity) in the Division of Environmental and Evolutionary Biology, University of Glasgow, Scotland, UK. Lobsters were fed ad libitum, once weekly on mussels Mytilus edulis but were not fed for at least $5 \mathrm{~d}$ prior to tissue collection. All lobsters were in the intermoult state (Aiken 1980) and were assessed for Hematodinium infection by the pleopod staging method of Field \& Appleton (1995). Individual pleopods were removed and viewed under low power microscopy.
The accumulation of agglutinated parasite and haemocyte material was used to assign the appropriate stage, whereby Stage 0 is apparently uninfected and Stages 1 to 4 are patently infected (stages of the parasite evident in the haemolymph).

Tissue removal and treatment. The DAF from each of 128 lobsters was dissected out under physiological saline, blotted to remove excess moisture and weighed (wet weight). Muscle tissue was then frozen in liquid nitrogen and freeze-dried for $36 \mathrm{~h}$ (Edwards 'Modulyo' freeze drier). Tissue was then re-weighed (dry weight) and samples were individually ground using a standard mortar and pestle. Ground samples were stored at $-20^{\circ} \mathrm{C}$ until analysis. For SDS-PAGE analysis of the DAF muscle, individual muscle fibres were dissected out in calcium-free physiological saline and placed into $200 \mu \mathrm{l}$ of SDS-sample buffer, denatured at $95^{\circ} \mathrm{C}$ for $4 \mathrm{~min}$ and stored at $-20^{\circ} \mathrm{C}$ until electrophoretic protein separation (Neil et al. 1993).

For electron microscopy, muscles were fixed for $2 \mathrm{~h}$ at room temperature in a solution containing $4 \%$ glutaraldehyde and $2 \%$ paraformaldehyde in $0.1 \mathrm{M}$ phosphate buffer, $\mathrm{pH} 7.4$, with $2 \%$ sucrose and $1.5 \%$ sodium chloride. Fixed samples were rinsed in $0.1 \mathrm{M}$ phosphate buffer with $4 \%$ sucrose and post-fixed in $1 \%$ osmium tetroxide in phosphate buffer for $1 \mathrm{~h}$. Specimens were washed in several changes of distilled water and stained in $0.5 \%$ uranyl acetate for $1 \mathrm{~h}$. Following dehydration through an ethanol series, specimens were embedded in Spurr resin (Spurr 1969). Thick sections $(1 \mu \mathrm{m})$ were stained with toluidine blue and suitable areas were thin-sectioned and mounted on uncoated copper/palladium grids and stained with uranyl acetate and lead citrate. Thin sections (60 to $70 \mathrm{~nm}$ ) were examined in a Zeiss 902 transmission electron microscope.

Chemicals. For protein and glycogen analyses, sodium hydroxide $(\mathrm{NaOH})$, trichloroacetic acid (TCA), potassium hydroxide $(\mathrm{KOH})$, ethanol $(\mathrm{EtOH})$ and the anthrone and Folin-Ciocalteu's phenol reagents were obtained from Sigma-Aldrich Co. (Poole, UK). For high performance liquid chromatography (HPLC) analysis, reagent-grade methanol $(\mathrm{MeOH})$, tetrahydrofuran (THF) and acetonitrile were obtained from BDH Laboratory Supplies (Leicestershire, UK). Crystalline amino acids (aspartate, glutamate, asparagine, serine, histidine, glutamine, glycine, threonine, arginine, alanine, tyrosine, valine, methionine, tryptophan, phenylalanine, isoleucine and leucine), taurine, sodium acetate, mercaptoethanol (ME) and $o$-phthaldialdehyde (OPT) were also from Sigma-Aldrich Co. and reagent-grade Millipore-filtered water was used throughout. For SDSPAGE, acrylamide-bis acrylamide $(30 \%)$, sodium dodecylsulfate (SDS), ammonium persulfate (APS), $N, N_{,} N^{\prime}, N^{\prime}-$ tetramethylethylenediamine (TEMED), brilliant-blue 
R250, TCA and relative molecular weight $\left(M_{\mathrm{r}}\right)$ standards were purchased from Sigma-Aldrich Co.

Muscle water and total protein assays. The muscle water content was determined for 128 lobsters as the difference between the wet weight and dry weight measurements. For determination of total muscle protein, $10 \mathrm{mg}$ of freeze-dried DAF from 117 lobsters was homogenised in $10 \mathrm{ml} 0.1 \mathrm{~N} \mathrm{NaOH}$, left for $12 \mathrm{~h}$ and centrifuged at $17000 \times g$ for $5 \mathrm{~min}$. One $\mathrm{ml}$ of the supernatant was added to $2 \mathrm{ml}$ of $10 \%$ TCA and left for $12 \mathrm{~h}$ at $4^{\circ} \mathrm{C}$ to allow for complete precipitation of the protein. Samples were centrifuged as above and the protein pellet re-dissolved in $1 \mathrm{ml}$ of $0.1 \mathrm{~N} \mathrm{NaOH}$. Aliquots of $0.5 \mathrm{ml}$ were then assayed for total protein using the Folin-Ciocalteu's phenol reagent (Lowry et al. 1951).

Muscle glycogen assay. For determination of muscle glycogen, $400 \mu \mathrm{l}$ of $30 \% \mathrm{KOH}$ was added to each of forty-five $10 \mathrm{mg}$ freeze-dried samples from lobsters at different stages of infection. The samples were boiled for $20 \mathrm{~min}$ in a water bath at 95 to $100^{\circ} \mathrm{C}$, cooled and added to $700 \mu \mathrm{l}$ absolute ethanol before being placed on ice for $2 \mathrm{~h}$. Following precipitation, samples were spun at $17000 \times g$ for $10 \mathrm{~min}$ and the supernatant discarded. One $\mathrm{ml}$ of distilled $\mathrm{H}_{2} \mathrm{O}$ was added to each sample before sonication, after which $50 \mu$ l was incubated at 95 to $100^{\circ} \mathrm{C}$ in $1 \mathrm{ml}$ of anthrone reagent before glycogen assessment (Carroll et al. 1956).

FAA measurement of muscle. For determination of muscle FAA concentrations, each of forty-four $10 \mathrm{mg}$ samples of freeze-dried DAF from lobsters at different stages of infection were sonicated in $1 \mathrm{ml} \mathrm{MeOH}$ for 1 min (De Vooys 1991). Sonicated samples were deproteinised for $30 \mathrm{~min}$ at $4^{\circ} \mathrm{C}$, following which the protein precipitate was removed by centrifugation at $17000 \times g$ for $10 \mathrm{~min}$. The supernatant was passed through a $0.22 \mu \mathrm{m}$ syringe filter before storage at $-70^{\circ} \mathrm{C}$ until analysis. Reverse phase HPLC was carried out as described in Stentiford et al. (1999) using $20 \mu \mathrm{l}$ of the DAF extract derivatized with $180 \mu \mathrm{l}$ OPT.

SDS-PAGE conditions. Samples of DAF muscle fibre were prepared as described above. Discontinuous SDS-PAGE was performed according to the method of Laemmli (1970) with $12.5 \%$ acrylamide separating gel and a $4 \%$ acrylamide stacking gel. Electrophoresis running conditions were as described by Neil et al. (1993), followed by overnight incubation in $10 \%$ TCA and staining for $30 \mathrm{~min}$ with Coomassie-blue solution. Stained gels were later examined with an Appligene ${ }^{\mathrm{TM}}$ gel imager.

Data analysis. Comparisons of the water content, protein, glycogen and FAA concentrations in the DAF muscle of uninfected and infected Nephrops norvegicus were performed either by 1-way analysis of variance (ANOVA) for normally distributed data, or by a Kruskal-Wallis test for non-normal distributions. Com- parisons between stages were made with a Tukey's pairwise analysis (normal distributions) and a MannWhitney test (non-normal distributions). Significance was considered to be at $\mathrm{p}<0.05$.

\section{RESULTS}

\section{Water assay of DAF muscle}

Percentage of water content in DAF muscle at all stages of infection showed small, but consistently elevated mean values, which were significantly different from the mean value for Stage $0(76.66 \%)$ for Stage 1 $(77.57 \%)(p<0.05)$, Stage $2(77.46 \%)(p<0.01)$ and Stage $3(77.77 \%)(p<0.01)$. At Stage 4 , an increase in DAF water was also observed, but was not significant $(77.43 \%)(p=0.095)$ (Fig. 1$)$.

\section{DAF muscle protein assay}

The protein concentration ( $\mathrm{mg} \mathrm{g}^{-1}$ dry wt) of DAF muscle showed no significant difference between uninfected (632.77 $\mathrm{mg} \mathrm{g}^{-1}$ dry wt DAF) and Hematodinium-infected lobsters $(\mathrm{p}=0.943)$. When expressed as $\mathrm{mg} \mathrm{g}^{-1}$ wet $w t$, the $\mathrm{p}$-value was reduced ( $\mathrm{p}=0.443$ ), but differences between uninfected and infected lobsters were still not significant.

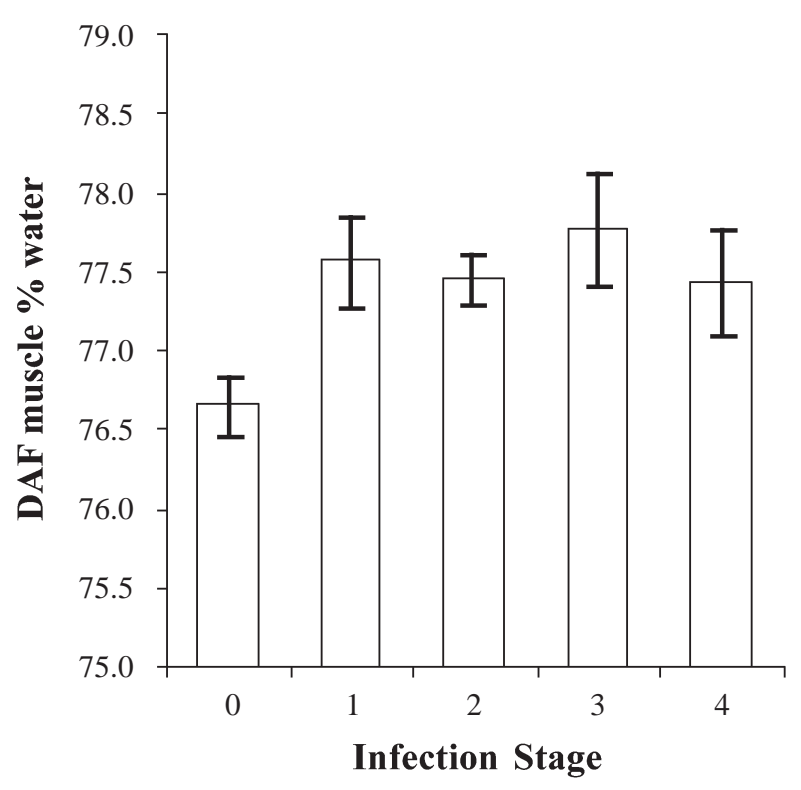

Fig. 1. Nephrops norvegicus. Percentage of water content in deep abdominal flexor (DAF) muscle from uninfected (Stage 0) and Hematodinium-infected (Stages 1 to 4 ) lobsters. Total $\mathrm{N}=$ 128; Stage 0, n= 24; Stage 1, $\mathrm{n}=23$; Stage 2, $\mathrm{n}=61$; Stage 3, $\mathrm{n}=15 ;$ and Stage $4, \mathrm{n}=5$ ) 


\section{DAF muscle SDS-PAGE analysis}

Myofibrillar proteins from DAF muscle fibres were separated using standard SDS-PAGE procedures. Fig. 2 shows that the protein banding pattern of Hematodinium-infected DAF is similar to that of the uninfected control, with no apparent qualitative differences in the relative content of the major myofibrillar proteins. Electrophoresis using high percentage acrylamide gels $(20 \%)$ confirmed this absence of extra bands in the low molecular weight region, while low percentage acrylamide gels (5 to $7 \%$ ) revealed no loss of bands in the high molecular weight region (data not shown).

\section{DAF muscle glycogen assay}

The glycogen concentration in the DAF muscle of uninfected Nephrops norvegicus had a mean value of $13.59 \mathrm{mg} \mathrm{g}^{-1}$ dry wt. This was progressively reduced in successive stages of Hematodinium infection to $8.36 \mathrm{mg} \mathrm{g}^{-1}$ dry wt in Stage $1(\mathrm{p}<0.001), 2.29 \mathrm{mg} \mathrm{g}^{-1}$ dry wt $(\mathrm{p}<0.001)$ in Stage $2,3.10 \mathrm{mg} \mathrm{g}^{-1}$ dry wt $(\mathrm{p}<0.001)$ in Stage 3 and $1.92 \mathrm{mg} \mathrm{g}^{-1}$ dry wt $(\mathrm{p}<$ 0.001 ) in Stage 4 . When different infection stages were compared, significant differences were found between

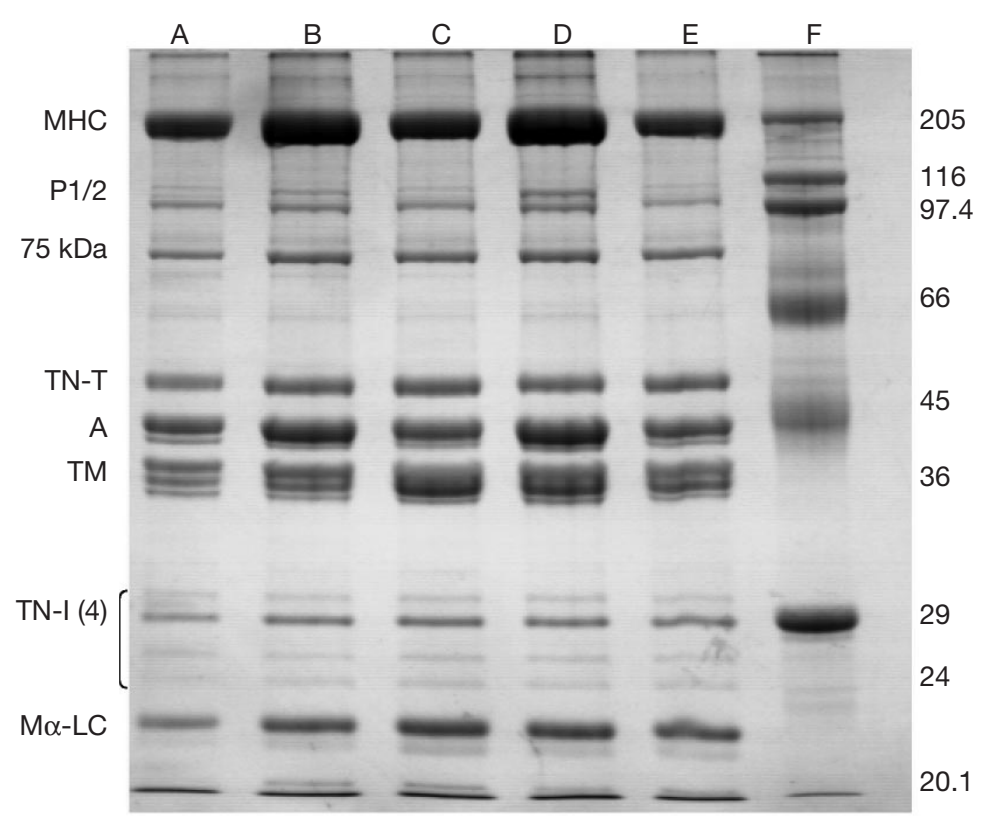

Fig. 2. Nephrops norvegicus. 12.5\% SDS-PAGE gel showing separation of contractile proteins from DAF fibres from uninfected and Hematodinium-infected lobsters. Lane A: Stage 0, B: Stage 1, C: Stage 2, D: Stage 3, E: Stage 4, F: molecular weight marker, MHC: myosin heavy chain, P1/2: paramyosin 1 and 2, $75 \mathrm{kDa}$ : unnamed fast muscle protein, $\mathrm{TN}$ T: troponin-T, A: actin, TM: tropomyosin, TN-I (4): 4 troponin-I isoforms, M $\alpha$-LC: myosin alpha light chain. Numbers on right indicate molecular weights in $\mathrm{kDa}$
Stage 1 and all other stages $(p<0.001)$, but not between Stages 2 and $3(p=0.273)$ or Stages 3 and 4 $(\mathrm{p}=0.194)$ (Fig. 3).

\section{FAA analysis of DAF muscle}

Concentrations ( $\mu \mathrm{mol} \mathrm{g}{ }^{-1}$ fresh wt) of FAA in DAF muscle of Nephrops norvegicus were derived from the areas of the various peaks on the HPLC chromatograms. The OPT-derivatized FAA compounds identified in the DAF muscle of lobsters with different levels of infection are shown in Table 1. In uninfected $N$. norvegicus (Stage 0), the total FAA concentration was $410.64 \mu \mathrm{mol} \mathrm{g}^{-1}$ fresh wt, with glycine, arginine, alanine, taurine and histidine/glutamine collectively constituting over $90 \%$. The total FAA concentration were highest in late stage infections, but was significantly different from uninfected DAF muscle only for Stage 4 animals $\left(486.39 \mu \mathrm{mol} \mathrm{g}^{-1}\right.$ fresh wt) $(\mathrm{p}<0.05)$.

The concentrations of several individual FAA compounds were altered significantly during Hematodinium-infection (Table 1). The histidine/glutamine concentration was reduced in early infection, while both aspartate and taurine reached their highest concentrations at Stage 2. Taurine is particularly noteworthy, being significantly higher than the control DAF at all stages of Hematodinium infection. Serine and phenylalanine shared a similar pattern, with increasing concentrations that peaked in Stage 3. Serine made the largest contribution to the increased total FAA concentration, changing from $5.99 \mu \mathrm{mol} \mathrm{g}{ }^{-1}$ fresh wt in uninfected animals to $24.06 \mu \mathrm{mol}$ $\mathrm{g}^{-1}$ fresh wt in Stage 4 of infection. Glycine, which accounted for over $70 \%$ of the total detected FAA in uninfected DAF, rose in concentration during infection, although the changes within stages were not significant (Table 1).

\section{Ultrastructure of DAF muscle fibres}

When infected Nephrops norvegicus were examined ultrastructurally, Hematodinium parasites were often observed in close association with fibres of the DAF muscle (Fig. 4C). Compared to normal muscle fibres (Fig. 4A), the sarcolemma of Hematodinium-infected muscle fibres was often disrupted with apparent disorganisation at the fibre periphery, separation of myofibrillar bundles and expansion of the tubular systems (Fig. 4B). The majority of the myofibrillar bundles located 
Table 1. Nephrops norvegicus. Summary of free amino acid (FAA) concentrations (in $\mu \mathrm{mol} \mathrm{g}^{-1}$ fresh wt) in the deep abdominal flexor (DAF) muscle of uninfected (Stage 0) and Hematodinium-infected (Stages 1 to 4 ) lobsters. ${ }^{*} p<0.05,{ }^{* *} p<0.01,{ }^{* * *} p<0.001$. Full names of amino acids are given in the 'Materials and methods' section

\begin{tabular}{|c|c|c|c|c|c|c|c|c|c|c|}
\hline \multirow[t]{3}{*}{ FAA } & \multicolumn{10}{|c|}{ DAF FAA concentrations $( \pm \mathrm{SE})$} \\
\hline & \multicolumn{2}{|c|}{ Stage $0(\mathrm{n}=10)$} & \multicolumn{2}{|c|}{ Stage $1(n=10)$} & \multicolumn{2}{|c|}{ Stage $2(\mathrm{n}=10)$} & \multicolumn{2}{|c|}{ Stage $3(n=9)$} & \multicolumn{2}{|c|}{ Stage $4(\mathrm{n}=5)$} \\
\hline & Conc. & $\mathrm{SE}$ & Conc. & $\mathrm{SE}$ & Conc. & $\mathrm{SE}$ & Conc. & SE & Conc. & SE \\
\hline Asp & 1.05 & $(0.15)$ & $2.46^{* * *}$ & $(0.42)$ & $3.21^{* * *}$ & $(0.35)$ & $1.91^{*}$ & $(0.35)$ & 1.75 & $(0.45)$ \\
\hline Glu & 3.88 & $(0.39)$ & $5.54^{* *}$ & $(0.42)$ & 3.76 & $(0.39)$ & 4.66 & $(0.74)$ & 4.27 & $(0.83)$ \\
\hline Asn & 4.22 & $(0.85)$ & 3.98 & $(0.29)$ & 3.61 & $(0.52)$ & 4.75 & $(0.60)$ & 4.62 & $(0.99)$ \\
\hline Ser & 5.99 & $(1.45)$ & $14.57^{*}$ & $(3.51)$ & 11.53 & $(2.75)$ & $26.06^{* *}$ & $(5.01)$ & $24.06^{* *}$ & $(4.56)$ \\
\hline His/Gln & 19.51 & $(2.89)$ & $11.49^{*}$ & $(0.90)$ & $9.18^{* *}$ & $(1.56)$ & $11.82^{*}$ & $(1.45)$ & 13.40 & (3.20) \\
\hline Gly & 300.81 & $(13.23)$ & 361.55 & $(26.56)$ & 329.71 & (26.30) & 329.33 & $(39.21)$ & 336.97 & $(34.28)$ \\
\hline Thr & 3.20 & $(0.72)$ & 3.49 & $(0.35)$ & 2.66 & $(0.62)$ & 5.00 & $(0.82)$ & 3.54 & $(1.03)$ \\
\hline Arg & 29.86 & $(2.38)$ & $19.00^{*}$ & (3.03) & 26.08 & $(3.47)$ & 35.76 & $(3.01)$ & 35.40 & $(4.65)$ \\
\hline Ala & 20.14 & $(3.55)$ & 23.01 & $(3.40)$ & 25.24 & $(2.11)$ & $33.25^{*}$ & $(4.60)$ & 29.14 & $(5.29)$ \\
\hline Tau & 12.17 & $(1.18)$ & $20.11^{* *}$ & $(2.03)$ & $27.17^{* * *}$ & $(3.61)$ & $24.91^{* *}$ & $(3.13)$ & $19.15^{*}$ & $(2.91)$ \\
\hline Tyr & 1.65 & $(0.27)$ & 1.10 & $(0.15)$ & $0.94^{*}$ & $(0.16)$ & 2.00 & $(0.52)$ & 2.19 & $(0.99)$ \\
\hline Val/Met & 3.24 & $(0.44)$ & 2.54 & $(0.18)$ & 2.26 & $(0.41)$ & 3.97 & $(0.73)$ & 4.52 & $(1.00)$ \\
\hline Phe & 0.38 & $(0.17)$ & $0.87^{*}$ & $(0.16)$ & 0.58 & $(0.09)$ & $1.96^{* *}$ & $(0.49)$ & 1.41 & $(0.73)$ \\
\hline Ile & 1.65 & $(0.42)$ & 1.62 & $(0.24)$ & 0.83 & $(0.16)$ & 2.66 & $(0.59)$ & 2.39 & $(0.70)$ \\
\hline Leu & 2.91 & $(0.50)$ & 2.76 & $(0.31)$ & 2.18 & $(0.55)$ & 3.95 & $(0.55)$ & 3.51 & $(0.72)$ \\
\hline Total FAA & 410.64 & $(15.21)$ & 474.11 & $(30.74)$ & 448.95 & (28.79) & 492.02 & $(45.72)$ & $486.39^{*}$ & (36.59) \\
\hline
\end{tabular}

more centrally in Hematodinium-infected DAF muscle fibres appeared normal in sarcomeric organisation, tubular systems and organelles (nuclei and mitochondria).

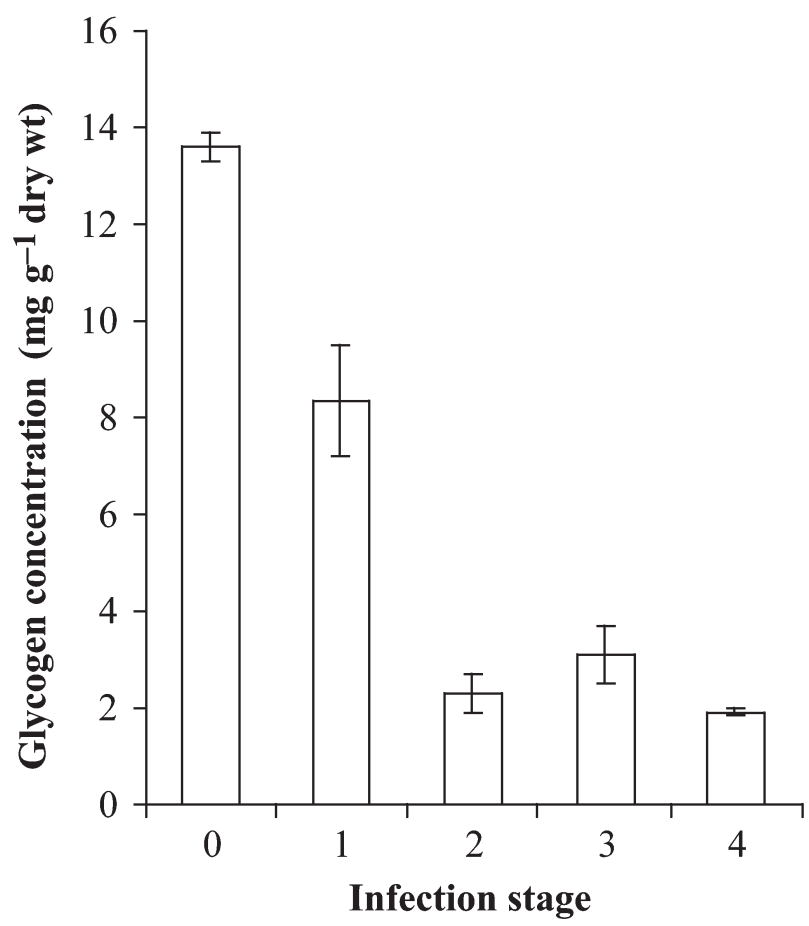

Fig. 3. Nephrops norvegicus. Concentrations of glycogen ( $\mathrm{mg} \mathrm{g}^{-1}$ dry wt) in DAF muscle from uninfected (Stage 0) and Hematodinium-infected (Stages 1 to 4 ) lobsters. Total $\mathrm{N}=45$; Stage 0, $\mathrm{n}=10 ;$ Stage 1, $\mathrm{n}=10 ;$ Stage 2, $\mathrm{n}=10 ;$ Stage 3, $\mathrm{n}=10$; and Stage $4, \mathrm{n}=5$ )

\section{DISCUSSION}

There are considerable alterations in the biochemistry and some changes in the ultrastructure of the abdominal musculature of Nephrops norvegicus during Hematodinium infection. There is a slight (up to $1.1 \%$ ) but significant increase in water content of DAF muscle during infection. The implications for this increase in DAF water for normal muscle function are not known, though it is possible that the dynamics of normal muscle contraction are altered (Field et al. 1995). An alteration in the water content may also affect the cooked meat texture and nutritional quality of infected $N$. norvegicus muscle.

Measurements of total DAF muscle protein $\left(\mathrm{mg} \mathrm{g}^{-1}\right.$ dry wt) provide an indirect indication of gross alterations that may occur during Hematodinium infection in Nephrops norvegicus. The data presented here show that, although there may be some association of the parasite with muscle bundles during heavy infections (Fig. 4C) (Field \& Appleton 1995), the total muscle protein concentration remains unaffected. The representation of the data as $\mathrm{mg} \mathrm{g}^{-1}$ wet wt emphasises the effect of the increase in DAF water on the total DAF protein concentration. The similarity between the total protein in the DAF muscle of infected and uninfected lobsters suggests that the general structure of this muscle is relatively unaffected during Hematodinium infection.

SDS-PAGE is a convenient tool for studying the expression of different contractile protein isoforms in crustacean muscle (Mykles 1985, Yoshinaka et al. 

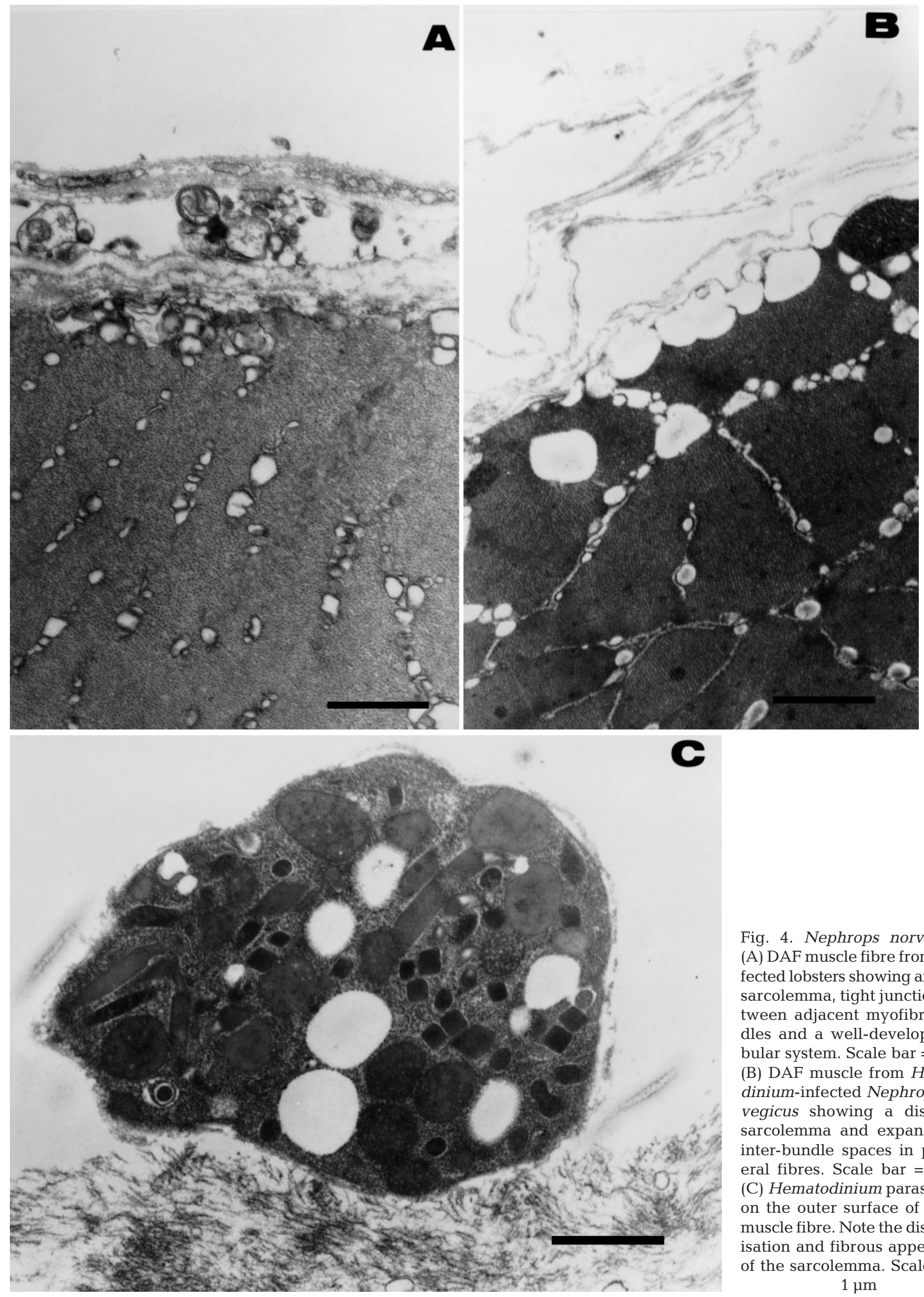

Fig. 4. Nephrops norvegicus. (A) DAF muscle fibre from uninfected lobsters showing an intact sarcolemma, tight junctions between adjacent myofibre bundles and a well-developed tubular system. Scale bar $=1 \mu \mathrm{m}$. (B) DAF muscle from Hematodinium-infected Nephrops norvegicus showing a disrupted sarcolemma and expansion of inter-bundle spaces in peripheral fibres. Scale bar $=1 \mu \mathrm{m}$. (C) Hematodinium parasite cell on the outer surface of a DAF muscle fibre. Note the disorganisation and fibrous appearance of the sarcolemma. Scale bar = 
1989, Youlin \& Mykles 1990, Neil et al. 1993, IshimodaTakagi et al. 1997). Fast muscle contains characteristic isoforms of paramyosin, troponin- $\mathrm{C}$, I and T (Mykles 1985 ) and a $75 \mathrm{kDa}$ protein that is cross-reactive with tropomyosin antibodies (Mykles 1997). In the current study, the DAF myofibrillar protein profile is largely unaltered during patent Hematodinium infection of Nephrops norvegicus (Fig. 2) and additional bands, indicative of breakdown fragments of muscle proteins, are also absent. These SDS-PAGE results are consistent with the measures of total protein, indicating that there is no significant alteration in muscle protein content during patent Hematodinium infection.

Ultrastructurally, most myofibrillar bundles in the interior of muscle fibres retain their normal organisation, even during heavy infection (Fig. 4) and the contractile machinery may produce normal levels of force, if activated. Alternatively, it cannot be excluded that the extensive disruption of sarcolemmal membrane structure of the DAF fibres which occurs during infection could prevent normal activation by affecting the distribution of ions across the sarcolemma. Fibres with lowered membrane resting potential would have reduced ability to respond to synaptic transmission with membrane depolarisations, and the subsequent steps in excitation-contraction coupling could then be suppressed. Thus, infected DAF muscle fibres may fail to contract in a normal way, although their contractile machinery is intact.

The presence of all major contractile proteins in Hematodinium-infected DAF fibres suggests that normal tail flexion (at least the part reliant on the proteins themselves) should still be possible. However, Stentiford et al. (2000) demonstrated that most parameters of the swimming performance of Nephrops norvegicus (including number of flips to exhaustion, total distance travelled and flip velocity) are reduced during progressing Hematodinium infection. This reduction in swimming performance does not reflect gross change in the total amount of contractile protein present, or to the breakdown of contractile machinery of Hematodinium-infected DAF muscle, but is related to more subtle factors either within the muscle itself, or in the supply of energy to support muscle contraction.

The most obvious change occurring in Hematodinium-infected DAF muscle is the reduction in the concentration of glycogen to approximately $15 \%$ of its normal value in Stage 4 of infection. Similar reductions in muscle glycogen concentration have been noted with bacterial infection by Aerococcus viridans var. homari in the lobster, Homarus americanus (Stewart 1980) and also with several nematode infections of insects; in locusts (Locusta migratoria and Schistocerca gregaria) (Jutsum \& Goldsworthy 1974 and Rutherford \& Webster 1978, respectively) and the mosquito Culex pipiens (Schmidt \& Platzer 1980). In these cases, the parasites may become a carbohydrate sink by consuming haemolymph glucose (the precursor for glycogenesis). Perhaps the parasites inhibit glycogen synthesis in the host, thereby allowing them to consume the host's glucose reserves (Rutherford \& Webster 1978). Interestingly, Schmidt \& Platzer (1980) have suggested that the condition of the host may establish the degree to which the parasites develop, with the growth of the parasites proceeding as the nutritional state of the host deteriorates. Such a feature in Hematodinium infection in Nephrops norvegicus would explain why infection prevalence is maximal during the spring, when lobsters are reaching their peak physiological condition before the onset of the main moulting season, while infection prevalence during the summer and autumn months is low (Field et al. 1998).

The reduction in the concentration of glycogen in DAF muscle during Hematodinium infection in Nephrops norvegicus may reflect changes in normal regulatory hormone function. Hyperglycaemia is a response to various stresses, and in crustaceans is mediated, at least in part, by the crustacean hyperglycaemic hormone $(\mathrm{CHH})$ (Chang et al. 1999). CHH released by the X-organ/sinus gland complex acts on the main glycogen reserve tissues (hepatopancreas, abdominal muscle and possibly hemocytes) to stimulate glycogenolysis, which increases extracellular glucose availability (Santos \& Keller 1993). A disruption, or upregulation of $\mathrm{CHH}$ release during Hematodinium infection may be partly responsible for depleting the DAF stores of muscle glycogen and liberating glucose, which is then utilized by the developing parasites.

Depletion of the DAF muscle glycogen reserve may also impact upon the swimming performance of Hematodinium-infected Nephrops norvegicus (Stentiford et al. 2000), with the reduced carbohydrate reserve causing a shortfall in the re-supply of ATP to the contractile machinery. In this study, the main reduction in DAF glycogen was seen at Stage 2 of Hematodinium infection, and Stentiford et al. (2000) reported that the main reduction in swimming performance also occurred at Stage 2 . The progressive reduction in carbohydrate reserves during Hematodinium infection may thus be the major factor in the reduced swimming performance. However, other features, such as the increased respiratory demand (Taylor et al. 1996) and loss of integrity of DAF muscle fibre membranes may also be important, especially during severe infections.

Like many marine invertebrates, crustaceans maintain high FAA concentrations within their cells for osmoregulation (Lange 1963) and alterations in the FAA profiles of muscles occur in various parasitic infections (Vivares et al. 1980, Findley et al. 1981). The total FAA concentration reported in this study for 
the DAF muscle of uninfected Nephrops norvegicus is comparable to that reported for the same species by Robertson et al. (1992), considering that proline, which was found by Robertson (1961) to be high in N. norvegicus muscle, was not derivatized using OPT in this study. During Hematodinium infection, the concentration of several FAA compounds was significantly altered. The largest changes were in serine and phenylalanine, which increased during progressing infection, and in taurine, which made the largest single contribution to the increase in total DAF muscle FAA. We have previously reported that plasma taurine increases significantly with severity of Hematodinium infection in N. norvegicus (Stentiford et al. 1999). Upregulation of taurine in the DAF muscle or a leakage of FAA compounds via the damaged sarcolemma of infected $N$. norvegicus may be partly responsible for this plasma increase (Finney 1978). If up-regulation in taurine synthesis is occurring, it may be the result of some form of stress reaction due to the large plasma parasite burden (Stentiford et al. 1999).

FAAs significantly affect the taste of crustacean meat, with differences in extractive components between species underlying their characteristic flavours (Hayashi et al. 1981, Shirai et al. 1996). Changes in the composition of FAAs and other compounds (nucleotides, sugars, organic acids and minerals) in the DAF may be implicated in the anecdotal changes in taste of Hematodinium-infected Nephrops norvegicus meat and also in the characteristic taste change accompanying 'bitter crab' infection in Tanner crabs Chionoecetes bairdi (Meyers et al. 1987). Detailed study of the extractive components from the muscles of $N$. norvegicus and Chionoecetes bairdi is necessary to identify the chemical basis of these taste alterations.

Acknowledgements. This work was supported by a contract from the Ministry of Agriculture Fisheries \& Food of the United Kingdom (Contract No. CSA 4172, Project code MFO221). The authors wish to thank Mr Mick Parker and the crew of the RV 'Aora' (University Marine Biological Station Millport) for assistance in collection and sorting of lobsters, and Ms Margaret Mullin for assistance with electron microscopy.

\section{LITERATURE CITED}

Aiken DE (1980) Moulting and growth. In: Cobb JS, Phillips BF (eds) The biology and management of lobsters. Academic Press, New York, p 91-163

Akiyama DM, Brock JA, Haley SR (1982) Idiopathic muscle necrosis in the cultured freshwater prawn (Macrobrachium rosenbergii). Vet Med Small Anim Clin 77:1119-1121

Anderson IG, Nash G, Shariff M (1990) Mass larval mortalities in giant freshwater prawn Macrobrachium rosenbergii de Man, cultured in Malaysian modified static 'green water' systems. J Fish Dis 13:127-134
Arnott SA, Neil DM, Ansell AD (1998) Tail-flip mechanism and size-dependent kinematics of escape swimming in the brown shrimp Crangon crangon. J Exp Biol 201: 1771-1784

Carroll NV, Longley RW, Roe JD (1956) The determination of glycogen in liver and muscle by use of the anthrone reagent. J Biol Chem 220:583-593

Cawthorn RJ (1997) Overview of 'bumper car' diseaseimpact on the North American lobster fishery. Int J Parasitol 27:167-172

Chang ES, Chang SA, Keller R, Sreenivasula Reddy P, Snyder MJ, Spees JL (1999) Quantification of stress in lobsters: crustacean hyperglycaemic hormone, stress proteins and gene expression. Am Zool 39:487-495

Childers RK, Reno PW, Olson RE (1996) Prevalence and geographic range of Nadelspora canceri (Microspora) in Dungeness crab Cancer magister. Dis Aquat Org 24:135-142

De Vooys CGN (1991) Anaerobic metabolism in sublittoral living Mytilus galloprovincialis in the Mediterranean-IV. Role of amino acids in adaptation to low salinities during anaerobiosis and aerobiosis. Comp Biochem Physiol Part A 100:423-431

Dennis DM, Munday BL (1994) Microsporidiosis of Palinurid lobsters from Australian waters. Bull Eur Assoc Fish Pathol 14:16-18

Eaton WD, Love DC, Botelho C, Meyers TR, Imamura K, Koeneman T (1991) Preliminary results on the seasonality and life cycle of the parasitic dinoflagellate causing bitter crab disease in Alaskan tanner crabs (Chionoecetes bairdi). J Invertebr Pathol 57:426-434

Field RH, Appleton PL (1995) A Hematodinium-like dinoflagellate infection of the Norway lobster Nephrops norvegicus: observations on pathology and progression of infection. Dis Aquat Org 22:115-128

Field RH, Appleton PL (1996) An indirect fluorescent antibody technique for the diagnosis of Hematodinium sp. infection of the Norway lobster, Nephrops norvegicus. Dis Aquat Org 24:199-204

Field RH, Chapman CJ, Taylor AC, Neil DM, Vickerman K (1992) Infection of the Norway lobster Nephrops norvegicus by a Hematodinium-like species of dinoflagellate on the west coast of Scotland. Dis Aquat Org 13:1-15

Field RH, Appleton PL, Vickerman K, Atkinson RJA, Taylor AC, Rogerson A, Neil DM, Shanks A (1995) Mortality of Nephrops norvegicus on the west coast of Scotland. Report to the Minsitry of Agriculture Fisheries and Food, London, UK. April 1995

Field RH, Hills JM, Atkinson RJA, Magill S, Shanks AM (1998) Distribution and seasonal prevalence of Hematodinium sp. infection of the Norway lobster (Nephrops norvegicus) around the west coast of Scotland. ICES J Mar Sci 55:846-858

Findley AM, Blakeney EW Jr, Weidner EH (1981) Ameson michaelis (Microsporidia) in the blue crab, Callinectes sapidus: parasite-induced alterations in the biochemical composition of host tissues. Biol Bull 161:115-125

Finney CM (1978) Isotopic labelling of taurine; implications for its synthesis in selected tissues of Homarus americanus. Comp Biochem Physiol Part B 61:409-413

FRS (1999) Nephrops stocks around Scotland. Fisheries Research Service (FRS) fish stocks information leaflet; December 1999. FRS, Aberdeen

Hayashi T, Yamaguchi K, Konosu S (1981) Sensory analysis of taste active components in the extract of boiled snow crab meat. J Food Sci 46:479-483

Hudson DA (1995) Biochemical parameters of the serum of the sand crab, Portunus pelagicus, with reference to the 
parasitic dinoflagellate, Hematodinium australis. Bull Eur Assoc Fish Pathol 15:202-205

Ishimoda-Takagi T, Itoh M, Koyama H (1997) Distribution of tropomyosin isoforms in spiny lobster muscles. J Exp Zool 277:87-98

Jutsum AR, Goldsworthy GJ (1974) Some effects of mermithid infection on metabolic reserves and flight in Locusta. Int $\mathrm{J}$ Parasitol 4:625-630

Kabre G (1992) Effects of the microsporidian Thelohania contejeani on the metabolism of total muscular and hepatopancreatic phospholipids in the crayfish Austropotamobius pallipes, Le Reboulet, 1858. Ann Sci Nat Zool Biol Anim 13:97-102

Laemmli UK (1970) Cleavage of structural proteins during assembly of the head of the bacteriophage T4. Nature 227:680-685

Langdon JS (1991) Microsporidiosis due to a pleistophorid in marron, Cherax tenuimanus (Smith), (Decapoda: Parastacidae). J Fish Dis 14:33-44

Lange R (1963) The osmotic function of amino acids and taurine in the mussel, Mytilus edulis. Comp Biochem Physiol 10:173-179

Lindqvist OV, Mikkola H (1978) On the etiology of the muscle wasting disease in Procambarus clarkii in Kenya. Freshw Crayfish 4:363-372

Lowry OH, Rosebrough NJ, Lewis Farr A, Randall RJ (1951) Protein measurement with the folin phenol reagent. J Biol Chem 193:265-275

Messick GA (1994) Hematodinium perezi infections in adult and juvenile blue crabs Callinectes sapidus from coastal bays of Maryland and Virginia, USA. Dis Aquat Org 19: $77-82$

Meyers TR, Koeneman TM, Botelho C, Short S (1987) Bitter crab disease: a fatal dinoflagellate infection and marketing problem for Alaskan tanner crabs Chionoecetes bairdi. Dis Aquat Org 3:195-216

Mykles DL (1985) Multiple variants of myofibrillar proteins in single fibres of the lobster claw muscles; evidence for two types of slow fibre in the cutter closer muscle. Biol Bull 169:476-483

Mykles DL (1997) Crustacean muscle plasticity: molecular mechanisms determining mass and contractile properties. Comp Biochem Physiol Part B 117:367-378

Neil DM, Ansell AD (1995) The orientation of tail-flip escape swimming in decapod and mysid crustaceans. J Mar Biol Assoc UK 75:55-70

Neil DM, Fowler WS, Tobasnick G (1993) Myofibrillar protein composition correlates with histochemistry in fibres of the abdominal flexor muscles of the Norway lobster Nephrops norvegicus. J Exp Biol 183:185-201

Newland PL, Neil DM (1990) The tail flip of the Norway lobster Nephrops norvegicus. I. Giant fibre activation in relation to swimming trajectories. J Comp Physiol Part A 166: 517-527

Newland PL, Neil DM, Chapman CJ (1992) Escape swimming in the Norway lobster. J Crust Biol 12:342-353

Robertson JD (1961) Studies on the chemical composition of

Editorial responsibility: Timothy Flegel,

Bangkok, Thailand muscle tissue. II. The abdominal flexor muscles of the lobster Nephrops norvegicus (L.). J Exp Biol 38:707-728

Robertson JD, Cowey CB, Leaf G (1992) The free amino acids in muscle of three marine invertebrates Nephrops norvegicus (L.), Limulus polyphemus (L.) and Eledone cirrhosa (Lamarck). Comp Biochem Physiol Part A 101:545-548

Rutherford TA, Webster JM (1978) Some effects of Mermis nigrescens on the hemolymph of Schistocerca gregaria. Can J Zool 56:339-347

Santos EA, Keller R (1993) Effects of exposure to atmospheric air on blood glucose and lactate concentration in two crustacean species: a role of the crustacean hyperglycaemic hormone $(\mathrm{CHH})$. Comp Biochem Physiol Part A 106: 343-347

Schmidt SP, Platzer EG (1980) Changes in body tissues and hemolymph composition of Culex pipiens in response to infection by Romanomermis culicivorax. J Invertebr Pathol 36:240-254

Shields JD (1994) The parasitic dinoflagellates of marine crustaceans. Annu Rev Fish Dis 4:241-271

Shirai T, Hirakawa Y, Koshikawa Y, Toraishi H, Terayama M, Suzuki T, Hirano T (1996) Taste components of Japanese spiny and shovel-nosed lobsters. Fish Sci 62:283-287

Spurr AR (1969) A low viscosity epoxy embedding resin for electron microscopy. J Ultrastruct Res 26:31-43

Stentiford GD, Neil DM, Coombs GH (1999) Changes in the plasma free amino acid profile of the Norway lobster Nephrops norvegicus at different stages of infection by the parasitic dinoflagellate (genus Hematodinium). Dis Aquat Org 38:151-157

Stentiford GD, Neil DM, Atkinson RJA, Bailey N (2000) An analysis of swimming performance in the Norway lobster Nephrops norvegicus L. infected by a parasitic dinoflagellate of the genus Hematodinium. J Exp Mar Biol Ecol 247: 169-181

Stewart JE (1980) Diseases. In: Cobb JS, Phillips BF (eds) The biology and management of lobsters. Academic Press, New York, p 301-342

Taylor AC, Field RH, Parslow-Williams PJ (1996) The effects of Hematodinium sp.-infection on aspects of the respiratory physiology of the Norway lobster Nephrops norvegicus (L.). J Exp Mar Biol Ecol 207:217-228

Taylor DM, Khan RA (1995) Observations on the occurrence of Hematodinium sp. (Dinoflagellata: Syndinidae), the causative agent of bitter crab disease in Newfoundland snow crab (Chionoecetes opilio). J Invertebr Pathol 65:283-288

Vivares CP, Cuq JL, Ceccaldi HJ, Richard PJ (1980) Influence d'une microsporidiose sur les acides aminés libres de Carcinus mediterraneus Czerniavsky, 1884 soumis à diverses salinitiés et à des valeurs extrêmes de température. J Exp Mar Biol Ecol 43:207-220

Yoshinaka R, Sato K, Itoh Y, Nakajima S, Sato M (1989) Content and partial characterisation of collagen in crustacean muscle. Comp Biochem Physiol Part B 94:219-223

Youlin L, Mykles DL (1990) Analysis of myosins from lobster muscles: fast and slow isozymes differ in heavy chain composition. J Exp Zool 255:163-170

Submitted: February 28, 2000; Accepted: May 9, 2000

Proofs received from author(s): July 21, 2000 